\title{
Using natural resource shocks to study economic behavior
}

\section{Natural resource shocks can help studying how low-skilled men respond to changes in labor market conditions}

Keywords: natural resource booms, labor market, low-skilled workers

\section{ELEVATOR PITCH}

In the context of growing worldwide inequality, it is important to know what happens when the demand for low-skilled workers changes. Because natural resource shocks are global in nature, but have highly localized impacts on labor prospects in resource extraction areas, they offer a unique opportunity to evaluate low-skilled men's behavior when faced with extreme variations in local labor market conditions. This situation can be utilized to evaluate a broad range of outcomes, from education and income, to marital and fertility status, to voting behavior.

\section{KEY FINDINGS}

\section{Pros}

$\oplus$ Changes in the market for natural resources produce large shocks that have highly localized labor impacts, creating ideal experimental research conditions.

๑ Changes in natural resource prices are most likely unrelated to local issues, which allows for the identification of causal impacts.

๑ Natural resource shocks provide more precise variation than many other types of instruments because the exact source of the expansion (or contraction) can be identified and the shocks are much larger in magnitude.

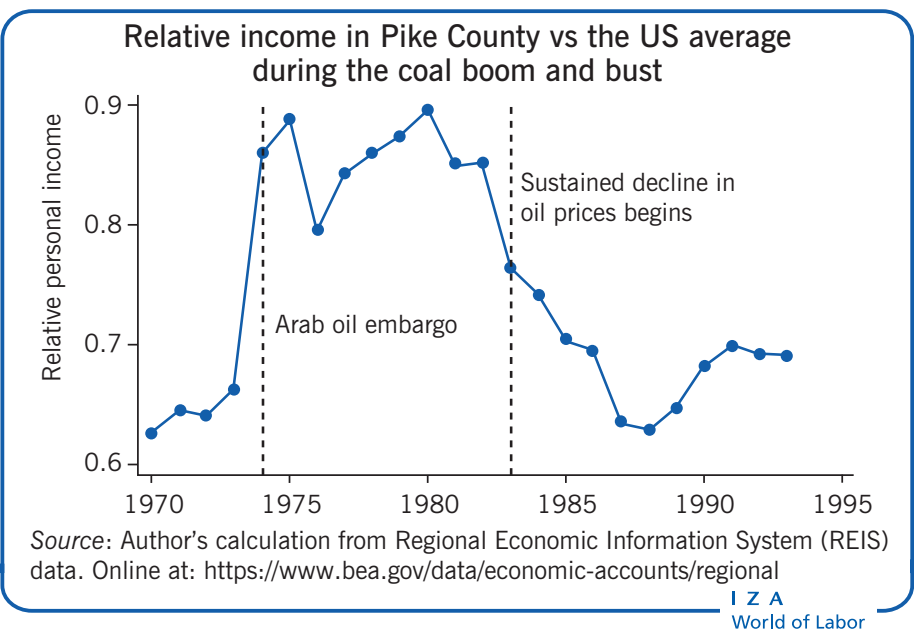

\section{Cons}

- Resource shocks may induce so-called "Dutch disease," in which natural resources retard (or accelerate) development in other sectors within the economy.

- Natural resource extraction work is heavily concentrated among low-skilled men, presenting a unique set of challenges.

- The presence of natural resources may generate longterm distortions in local labor markets, which may compromise the external validity of the experiment.

- While important, the study of natural resource shocks does little to identify policies that facilitate the re-employment of low-skilled workers.

\section{AUTHOR'S MAIN MESSAGE}

Shocks in natural resource markets induce large changes in demand that can be exploited to test how demand shocks affect local markets. Natural resource shocks have been used to study how local labor markets influence a wide range of behaviors including education, fertility, public assistance use, marriage rates, voting behavior, the local provision of public goods, and health care use. Though existing research using natural resource shocks has not yet put forth specific policy recommendations, it is clear that low-skilled men would benefit from policies that support their transition into alternative labor opportunities after resource booms expire. 


\section{MOTIVATION}

There is a great deal of volatility associated with prices for natural resources. This often results in huge labor market shocks in isolated areas. Researchers can exploit these events to examine the consequences of such shocks on a host of important outcomes, including educational attainment and marriage rates.

It can be difficult to determine the impact of modest economic shocks on outcomes such as these. However, when the shocks are significant, the results can be quite obvious. The illustration on page 1 demonstrates this point. It reflects the per capita total personal income (TPI) in Pike County, US, one of Kentucky's larger coal producing counties, from 1970 to 1995. In 1972, Pike County's TPI was just 64\% of the national average; by 1975 , due to a locally based natural resource shock occurring as a result of the Arab oil embargo, it had risen to $89 \%$ of the national average. The decline in natural resources can have equally large consequences. From its peak in 1980, per capita TPI fell from 90\% of the national average to just $63 \%$ in 1987 , in line with sustained declines in global oil prices. Such large shocks make the detection of even modest responses relatively straightforward. Thus, natural resource shocks provide an interesting experiment through which researchers can see how a wide range of behaviors respond to large labor market swings.

Furthermore, large swings in international prices, which go hand in hand with natural resource shocks, are not the consequence of any local economic activity. This means researchers can be sure that such shocks are not the consequence of any lurking "confounder" that may influence both the local labor market and the outcome of interest. The independence of such shocks from local economic conditions allows researchers to identify the causal impact of local labor market shocks on the outcomes of interest. Such large and often persistent shocks are difficult to find in most economies. Hence, these shocks provide an important laboratory for social scientists.

Of course, social science research is not interested in learning about the past but rather in examining these past labor market shocks to determine how future shocks might affect economic outcomes. In the parlance of experimental design, researchers want these shocks to have "external validity": the idea is that by studying such shocks researchers and policymakers can learn how future economic agents will respond to similar shocks.

\section{DISCUSSION OF PROS AND CONS}

\section{Overview and summary of past literature}

In 1995, Will Carrington published an intriguing study about how the construction of the Trans-Alaskan Pipeline System (TAPS) from 1974 to 1977 affected Alaska's economy. Alaska at the time was a very small state, with a population of about 400,000 people. To put that in perspective, this would only be the seventh largest county in today's Chicago metropolitan area. Yet, TAPS was the largest privately financed construction project ever attempted. Simply put, Alaska did not have the necessary workforce to complete such a project. In his study, Carrington documents the remarkable flexibility of the Alaskan low-skilled labor market to find the necessary skilled and unskilled workers to complete such a massive project.

Other researchers have explored how similar resource shocks affect local economies for the low skilled, or examine the long-term consequence of resource endowments on economies [1], [2], [3], [4]. These studies also find remarkable flexibility within local economies to accommodate the large demand shocks associated with natural resource shocks. While 
these results are certainly interesting, economists recognize that such shocks could further help understand how a wide range of other economic activity is affected.

In October 1973, OPEC's oil embargo of the US, and other countries perceived to have supported Israel in the Yom Kippur War, induced a massive increase in coal prices. While for most of the world's economies this dramatic increase in energy prices was traumatic, areas with coal and oil boomed. Figure 1 shows the real price of coal during this period; there clearly was a sharp price increase in line with the oil embargo. At least through the mid-1980s, the pattern of relative TPI in Pike County, Kentucky, as shown in the illustration on page 1, is indistinguishable from the real price of coal: demand for labor increased and earnings followed.

Figure 1. The real price of coal

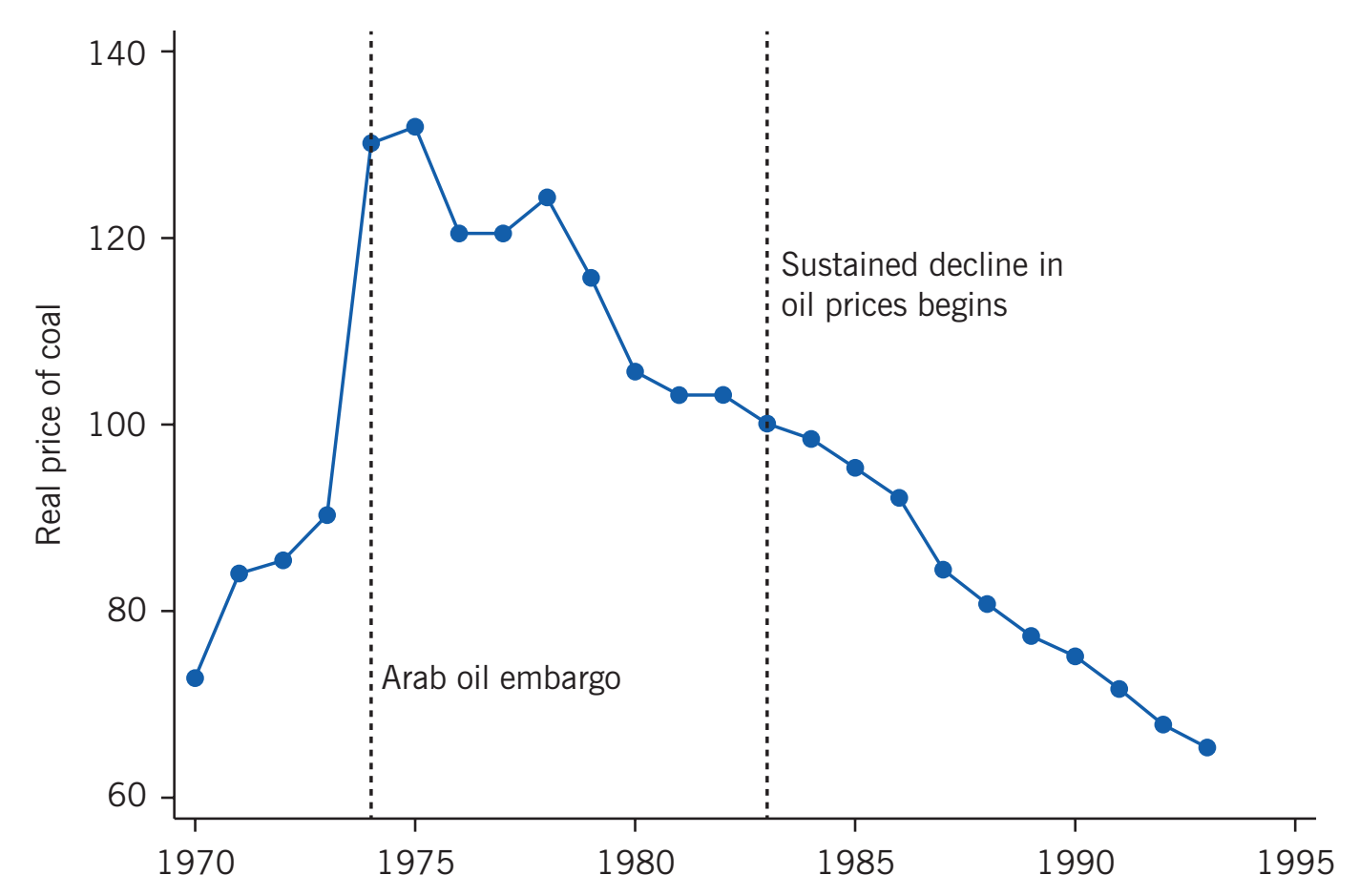

Source: Author's calculations from the Bureau Labor Statistics, Consumer Price Index and Producer Price Index for coal. Online at: https://www.bls.gov/ppi/

A study from 2002 uses this sizable shock to examine the impact of local labor market conditions for low-skilled men on the take up of two US disability programs: the Social Security Disability Insurance program (SSDI) (which is a social insurance program) and Supplemental Security Income (SSI) (which is a means-tested program for people who do not qualify or only partially qualify for SSDI) [4]. The authors focus on four Appalachian states-Kentucky, Ohio, Pennsylvania, and West Virginia-which represented some of the poorest areas in the US at that time. Despite coal being particularly dangerous work, the authors find that disability payments actually declined substantially during the coal boom and increased during the coal bust. They find that a $10 \%$ increase in local labor market earnings decreased SSDI payments by about 3.5\%. Similarly, a $10 \%$ increase in local labor market earnings reduced SSI payments within a county by about $6.4 \%$. Thus, local labor market conditions appear to be a very important determinant of disability recipiency. 


\section{Natural resource shocks afford opportunities to study a wide range of outcomes}

Because of the magnitude of these shocks, it is not surprising that researchers have used them to examine a wide variety of economic behaviors, including fertility [5], public assistance use and marriage rates [6], voting behavior [7], the local provision of public goods [8], health care use, [9], and education [10], [11], [12].

\section{Resource shocks and fertility and male income}

In his classic work on the economics of fertility, Becker (1960) suggests that children are likely "normal goods" (goods that demand more as a consumer's income increases) but the evidence for the claim has been mixed. The authors of a 2013 study delve further into this topic by first examining local differences in fertility behavior in the US (Black et al., 2013). When they compare women living in areas experiencing resource shocks with other similarly educated women living in similarly expensive locations, completed fertility is positively correlated with the husband's income. In an effort to sort out causal effects, the authors analyze the localized impact on fertility of the increase in world energy prices in the mid-1970s, an exogenous shock that substantially increased men's incomes in the Appalachian coal-mining region. Empirical evidence for this population shows that fertility increases with the growth in men's income during the resource boom and declines with the fall in men's income during the bust.

Sources: Becker, G. S. "An economic analysis of fertility." In: Demographic and Economic Change in Developed Countries. New York: Columbia University Press, 1960; Black, D., N. Kolesnikova, S. Sanders, and L. Taylor. "Are children normal?" Review of Economics and Statistics 95:1 (2013): 21-33.

\section{Resource shocks and employment, earnings, and voting}

Using county-level data across several decades, a study published in 2013 finds that higher local wages and employment rates (the results of resource shocks) lead to lowervoter turnout in elections for governor, senator, US representatives, and state house of representatives races, but have no effect on presidential turnout (Charles and Stephens, 2013).

Source: Charles, K., and M. Stephens, Jr. "Employment, wages and voter turnout." American Economics Journal: Applied Economics 5:4 (2013): 111-143.

\section{Resource shocks and local labor market conditions and local public goods}

The authors of a 2013 study use the considerable variation in oil output among Brazilian municipalities to explore the effects of resource windfalls on government behavior (Caselli and Michaels, 2013). Oil-rich municipalities experience increases in revenues and report corresponding increases in spending on public goods and services. Corresponding survey and administrative data indicate public goods provision and household income increase less than expected.

Source: Caselli, F., and G. Michaels. "Do oil windfalls improve living standards? Evidence from Brazil.” American Economics Journal: Applied Economics 5:1 (2013): 208-238. 


\section{Are findings from specific events generalizable across time and location?}

While it is clear that a wide range of topics have been analyzed, it is perhaps not so clear whether these findings are generalizable to other periods of time and areas of the world. Toward this end, a couple of studies address the serious issue known as "Dutch disease." Growth and trade economists have long-posited that having an abundance of natural resources can crowd out development in other industries. Cross-country studies have found that countries with large endowments have fewer exports of non-natural resource products, and growth has been lower for countries with large endowments of natural resources. Recent work has examined how oil and energy resources affect the development of areas with such endowments [2], [3].

One study looks at several US states (Colorado, New Mexico, Kansas, Oklahoma, Texas, Missouri, Arkansas, Louisiana, Tennessee, Mississippi, and Florida), comparing their development as of 1890 and then comparing outcomes from 1940 to 1990 [2]. The author finds that having an endowment of oil facilitated development. As the author states, "in 1940, about 50 years after oil was first discovered, its effects were large and beneficial. By the middle of the twentieth century, the development of the oil sector increased education and per capita income in oil-abundant counties without increasing local income inequality. Oil abundance also increased the employment share of the extraction sector mostly at the expense of agriculture and it had little impact on the employment share of manufacturing. But while oil abundance did not change the employment share of manufacturing, it did affect overall manufacturing employment density, increasing it by at least 50\%" [2], p. 52. In other words, the study finds that the existence of oil facilitated economic growth and development in the endowed areas.

Another study from 2018 produces similar findings, although the focus is on a much more recent period (1969-2014) [3]. The authors consider the endowments of oil and natural gas within a county and examine how shocks to the energy sector affect both short-term and long-term effects on the local economy. Unlike earlier works [1], [2], this study finds some evidence of short-term crowding-out of employment in certain manufacturing sectors, but these sectors' productivities or revenues did not decline. Moreover, any reduction in employment in these sectors was strictly temporary. As the authors conclude, "we find evidence against each link in the hypothesized Dutch disease chain of events. Manufacturing plants in resource-abundant counties benefit a surprising amount from local demand growth, manufacturing productivity does not decrease, and overall, there is no Natural Resource Curse: oil and gas abundance increases cumulative local wages and welfare" [3], p. 698.

Thus, there appears to be little evidence that areas with an abundance of natural resources are materially different economically from similar areas without natural resources. This is an important finding both for growth and trade economists who worry about the Dutch disease and for economists who wish to use resource shocks as instruments for changes in local labor market demand. But while the energy rich areas of, for example, Appalachia (the coal rich region of the Appalachian mountains in the eastern US) might be similar to other areas of Appalachia without energy, it is still the case that Appalachia remains a unique and peculiar place, with extremely low incomes and education levels relative to the rest of the US and other developed countries. Given the numerous studies that have used the Appalachian shock, researchers might wish to know whether the results of these studies have the desired "external validity." 
To see how well one may generalize these results, it is useful to examine two areas where the topics have been analyzed across both time and countries.

Human capital theory predicts that individuals acquire less schooling when the returns to schooling are reduced. To test this theory, the authors of a 2005 study examine the effect of the coal boom in Appalachia on high school enrollments [10]. During the 1970s, the coal boom increased the earnings of high school dropouts relative to graduates. During the 1980s, the boom subsided and the earnings of high school dropouts declined relative to graduates. The authors found that high school enrollment rates declined considerably in the 1970s and increased in the 1980s in coal producing counties relative to counties without coal. A more recent study also finds very large impacts on high school enrollment from the fracking boom in states with shale deposits during the 2000s.

In contrast, another study from 2012 explores the impact of the 1973-1981 oil boom in Alberta, Canada [11]. The authors find some evidence that the oil boom may have altered the time of education, particularly in relation to post-secondary education, but there appears to be no evidence that the oil boom affected the ultimate educational attainment of Alberta men. A 2015 study supports this finding via an examination of the later 2001-2008 oil boom [12].

The differences between US and Canadian results are summarized in Figure 2. The contrast between results is intriguing, though it must be mentioned that Alberta is a relatively wealthy province within Canada, and its schools have an excellent reputation, whereas Appalachia is a US region on the other end of both spectrums. Even so, the fact that two different shocks seem to produce consistent and contrasting outcomes in the US and Canadian settings is highly interesting.

\section{Examining the impact of natural resource shocks on the utilization of disability insurance}

A second area of research with an interesting replication is that of disability insurance take-up and local labor market conditions. A recent study from 2018 uses data from oil-producing US states between 1970 and 2011 [13] to compare findings with a previously referenced 2002 study [5]. Examining data through 2011 allows the authors of the more recent study to examine the long bust from the late 1980 s to the later 1990s, and the subsequent boom beginning at the turn of the century. The authors' focus on more recent cohorts and 11 states largely in the American West offers a very different experiment. The authors argue, "To the extent that disability benefits offer higher replacement rates to lower-earning workers [...] disability take-up for the typical American worker, who more closely resembles the oil and gas workers we study, may exhibit very different responses to earnings shocks than do coal workers to shocks in their sector" [13], p. 416.

Despite these differences, the results are remarkably consistent across the two studies. The earlier study estimates that a $10 \%$ increase in earnings would reduce SSDI payments by $3.5 \%$, while the estimate is $2.9 \%$ in the 2018 study. Again from the 2018 work, the authors note, "we find a similar relationship in a more nationally representative set of states, among more educated persons, and during a much more recent time period. This somewhat surprising result suggests that the response of disability take-up to market 
Figure 2. Comparison of the impact of natural shocks on education outcomes

\begin{tabular}{|l|l|l|l|}
\hline Location & $\begin{array}{l}\text { Shock (OPEC or } \\
\text { 2000s) }\end{array}$ & $\begin{array}{l}\text { Education } \\
\text { measure }\end{array}$ & $\begin{array}{l}\text { Impact of energy } \\
\text { shock on education } \\
\text { (permanent or } \\
\text { temporary) }\end{array}$ \\
\hline $\begin{array}{l}\text { US (Kentucky and } \\
\text { Pennsylvania) }\end{array}$ & OPEC & $\begin{array}{l}\text { High school } \\
\text { graduation }\end{array}$ & Permanent \\
\hline Canada (Alberta) & OPEC & Attainment & Temporary \\
\hline $\begin{array}{l}\text { Canada (Alberta, } \\
\text { Saskatchewan and } \\
\text { Newfoundland) }\end{array}$ & 2000s & Attainment & Temporary \\
\hline $\begin{array}{l}\text { US (Colorado, } \\
\text { Louisiana, Maryland, } \\
\text { Montana, Nebraska, } \\
\text { New Mexico, } \\
\text { New York, } \\
\text { North Dakota, } \\
\text { Ohio, Oklahoma, } \\
\text { Pennsylvania, } \\
\text { Texas, Virginia, } \\
\text { and West Virginia) }\end{array}$ & 2000s & Attainment & Permanent \\
\hline
\end{tabular}

Note: OPEC=1973 OPEC oil embargo; 2000s=US fracking boom.

Source: OPEC shock: US: Black, D., T. McKinnish, and S. Sanders. "The economic impact of the coal boom and bust. "Economic Journal 115:502 (2005): 444-471 [1]; Canada: Emery, H., A. Ferrer, and D. Green. "Long-term consequences of natural resource booms for human capital accumulation."Industrial and Labor Relation Review 65:3 (2012): 708-734 [11]; 2000s shock: US: Cascio, E. C., and A. Nayaran, Who Needs a Fracking Education? The Educational Response to Biased Technological Change. Dartmouth University Working Paper, 2017; Canada: Morissette, R., P. Chan, and Y. Lu. "Wages, youth employment and school enrollment: Recent evidence from increases in world oil prices."Journal of Human Resources 50:1 (2015): 222-253 [12].

conditions is similar across areas and disability programs, despite different targeted populations for SSDI and SSI programs" [13], p. 442.

\section{LIMITATIONS AND GAPS}

The differences between the education results (which compare Canada and the US) and those on disability insurance (which compare two different regions of the US), illustrate well the limitation of current research in this area. Because the research has so far used a reduced-form approach (i.e. the result of a descriptive regression rather than a fully specified economic model), it is thus not possible to tell if the differences between the Canadian and US Appalachian results are a consequence of differences in wealth, the education systems of Alberta and Appalachia, or differences in the economies of the two regions. The similarities in the Canadian education results across time, and the similarity of the US disability results across time and region, might suggest that institutional differences between the countries are the determining factors.

The similarity of the Canadian results and the similarity of the US results, however, arise despite fundamental changes in the economies across time. For the education results, 
there has been a tremendous increase in the measured earnings gaps between the highly educated and less educated. In the US, there has been a remarkable growth in SSDI participation so that the program in the later periods is admitting a different portion of the distribution than the program in the earlier periods. Do these differences mask an underlying heterogeneity in the estimates? Are the similarities in the Canadian results and the US Appalachian results a happy coincidence that masks a highly variable estimate?

This issue, of course, affects all reduced-form estimates in economics. Researchers in general spend too little time assessing how results are generalized from the particular "experiment" under analysis. The natural resource shocks, however, would appear to be particularly open to concerns about external validity. Natural resources are generally located in largely rural areas. In the US, Appalachia and the American south are historically impoverished areas. In contrast, Alberta is a particularly wealthy province in Canada. Attempting to better understand how these differences affect the external validity of the estimates, while a tall order, is the order of the day.

\section{SUMMARY AND POLICY ADVICE}

Policymakers and researchers alike are subjected daily to the mantra of "data-driven decisions" but are seldom told how to use the data to drive the decision. Undoubtedly, while the information learned from the analysis of the natural resource booms and busts is useful for informing policy, its applicability to today's very different events and populations remains in doubt.

Much has worked against low-skilled men in today's advanced economies. Their earnings and labor market participation have been falling, their health deteriorating, and their economic prospects in long-term decline. Given the prevalence of low-skilled men in natural resource extraction, natural resource shocks offer an opportunity to examine how their behavior changes in response to labor market shocks. The results are not encouraging. Their participation in disability programs grows [4], [7], their in-wedlock fertility rates decline [5], they spend less on health care [9], and they get divorced from their spouses at a higher rate [6]. The communities they live in have higher rates of welfare use [6] and have lower rates of investment in public goods [8].

These are all bad outcomes. Policymakers would thus do well to consider policies that would improve low-skilled men's transition back into the labor market after a natural resource shock. Sadly, little effort has been made to assist low-skilled men displaced by energy shocks so there is little guidance to be gleaned from these studies.

Despite the lack of existing evidence upon which to base policy recommendations, research is ongoing. Recent studies look at internal migration, the political economy associated with education in Texas during the oil shale boom, and intergenerational mobility. With continued efforts, such research should lead to actionable policy recommendations that could be put into place during the next wave of natural resource booms. 


\section{Acknowledgments}

The author thanks anonymous referees and the IZA World of Labor editors for many helpful suggestions on earlier drafts. Previous work of the author contains a larger number of background references for the material presented here and has been used intensively in all major parts of this article.

\section{Competing interests}

The IZA World of Labor project is committed to the IZA Code of Conduct. The author declares to have observed the principles outlined in the code.

(C) Dan A. Black 


\section{REFERENCES}

\section{Further reading}

Carrington, W. "The Alaskan labor market during the pipeline era." Journal of Political Economy 104:1 (1996): 186-218.

Marchand, J. "The distributional impacts of an energy boom in Western Canada." Canadian Journal of Economics 48:2 (2015): 714-735.

\section{Key references}

[1] Black, D., T. McKinnish, and S. Sanders. "The economic impact of the coal boom and bust." Economic Journal 115:503 (2005): 449-476.

[2] Michaels, G. "The long term consequences of resource-based specialisation." Economic Journal 121:551 (2011): 31-57.

[3] Allcott, H., and D. Keniston. "Dutch disease or agglomeration? The local economic effects of natural resource booms in modern America." Review of Economics Studies 85:2 (2018): 695-731.

[4] Black, D., K. Daniel, and S. Sanders. "The impact of economic conditions on disability program participation: Evidence from the coal boom and bust." American Economic Review 92:1 (2002): 2750 .

[5] Black, D., N. Kolesnikova, S. Sanders, and L. Taylor. "Are children normal?" Review of Economics and Statistics 95:1 (2013): 21-33.

[6] Black, D., T. McKinnish, and S. Sanders. "Does the availability of high-wage jobs for low-skilled men affect welfare expenditures? Evidence from shocks to the steel and coal industries." Journal of Public Economics 87:9-10 (2003): 1921-1942.

[7] Charles, K., and M. Stephens, Jr. "Employment, wages and voter turnout." American Economic Journal: Applied Economics 5:4 (2013): 111-143.

[8] Caselli, F., and G. Michaels. "Do oil windfalls improve living standards? Evidence from Brazil." American Economic Journal: Applied Economics 5:1 (2013): 208-238.

[9] Acemoglu, D., A. Finkelstein, and M. Notowidigdo. "Income and health spending: Evidence from oil price shocks." Review of Economics and Statistics 95:4 (2013): 1079-1095.

[10] Black, D., T. McKinnish, and S. Sanders. "Tight labor markets and the demand for education: Evidence from the coal boom and bust." Industrial and Labor Relations Review 59:1 (2005): 3-16.

[11] Emery, H., A. Ferrer, and D. Green. "Long-term consequences of natural resource booms for human capital accumulation." Industrial and Labor Relation Review 65:3 (2012): 708-734.

[12] Morissette, R., P. Chan, and Y. Lu. "Wages, youth employment and school enrollment: Recent evidence from increases in world oil prices." Journal of Human Resources 50:1 (2015): 222-253.

[13] Charles, K., Y. Li, and M. Stephens, Jr. "Disability benefit take-up and local labor market conditions." Review of Economics and Statistics 100:3 (2018): 416-423.

\section{Online extras}

The full reference list for this article is available from:

https://wol.iza.org/articles/using-natural-resource-shocks-to-study-economic-behavior

View the evidence map for this article:

https://wol.iza.org/articles/using-natural-resource-shocks-to-study-economic-behavior/map 